\title{
Phosphate-polymer-dependent Phosphorylation of Glycolytic Substrates by Brevibacterium Species
}

\author{
By NORIKO OKAMOTO, HAJIME TEI, KOUSAKU MURATA* \\ AND AKIRA KIMURA \\ Research Institute for Food Science, Kyoto University, Uji, Kyoto 611, Japan
}

(Received 12 November 1985 ; revised 17 December 1985)

\begin{abstract}
Phosphate polymer-utilizing activity for the phosphorylation of glucose, mannose, fructose and fructose 6-phosphate was investigated in 12 Brevibacterium species. Almost all the species were able to phosphorylate sugars using metaphosphate as a phosphoryl donor. However, only $B$. pusillum was able to phosphorylate fructose 6-phosphate to fructose 1,6-bisphosphate using pyrophosphate. The analysis of cell extracts prepared from $B$. pusillum indicated that at least two enzymes were responsible for the phosphate-polymer-dependent phosphorylation of sugars and fructose 6-phosphate.
\end{abstract}

\section{INTRODUCTION}

Evidence accumulated in recent years has stongly suggested the possible replacement of ATP by phosphate polymers in many energy-requiring reactions of aerobic and anaerobic bacteria (Harold, 1966) and various types of plant cells. Murata et al. (1980a) have demonstrated a metaphosphate-dependent phosphorylation of $\mathrm{NAD}^{+}$in many strains of Brevibacterium and Micrococcus. Tryon \& Pollack (1984) have detected a pyrophosphate-dependent phosphorylation of purine nucleosides to the corresponding nucleotides in Acholeplasma laidlawii. A pyrophosphate-dependent phosphofructokinase activity has also been detected in a parasitic amoeba (Reeves et al., 1974), a bacterium (O'Brien et al., 1975) and in pineapple leaves (Carnal \& Black, 1979) and a number of other plants (Sabularse \& Anderson, 1981; Cseke et al., 1982; van Schaftingen et al., 1982; Kruger et al., 1983; Wu et al., 1983; Stitt et al., 1982).

These observations indicate the important role of phosphate polymers in the phosphorylation of biological metabolites and lead one to doubt that energy or phosphorus storage is the principal function of phosphate polymers. In this communication, we present evidence that in Brevibacterium pusillum, phosphate polymers are able to replace ATP in the energy-requiring reactions of glycolysis.

\section{METHODS}

Cultivation and preparation of cell extracts. Brevibacterium species (see Table 1) were grown in a nutrient medium comprising glucose $(1 \%, w / v)$, yeast extract $(1 \%$, w/v), meat extract $(1 \%, w / v)$ and peptone $(1 \%, w / v)(\mathrm{pH} 7.0)$ at $30{ }^{\circ} \mathrm{C}$ for $24 \mathrm{~h}$ with reciprocal shaking. The cells were harvested, washed once with chilled $0.85 \%(\mathrm{w} / \mathrm{v}) \mathrm{NaCl}$, resuspended in $5.0 \mathrm{~mm}$-Tris $/ \mathrm{HCl}$ buffer $(\mathrm{pH} 7.0)$ containing $1.0 \mathrm{~mm}$-dithiothreitol and $30 \%(\mathrm{w} / \mathrm{v})$ glycerol (Tris/DTT/glycerol) and sonicated at $90 \mathrm{kHz}$ for $10 \mathrm{~min}$ at $0{ }^{\circ} \mathrm{C}$. The resulting cell extracts were centrifuged at $25000 \mathrm{~g}$ for $30 \mathrm{~min}$ and the clear supernatants were dialysed against Tris/DTT/glycerol at $4{ }^{\circ} \mathrm{C}$ overnight.

$D E A E$-cellulose column chromatography. To separate the phosphate-polymer-dependent activities, the cell extracts were applied to a DEAE-cellulose column $(5 \times 15 \mathrm{~cm})$ equilibrated with Tris/DTT/glycerol; proteins were eluted with a linear gradient of $0-1 \mathrm{M}-\mathrm{NaCl}$ in the same buffer (total vol. $400 \mathrm{ml}$ ) at a flow rate of $2 \mathrm{ml} \mathrm{min}^{-1}$ (fraction vol. $2 \mathrm{ml}$ ).

Enzyme assays. For the assay of phosphate-polymer- and ATP-dependent activities, $1.0 \mathrm{ml}$ of a reaction mixture containing phosphoryl donor, phosphoryl acceptor, $2.5 \mathrm{mM}-\mathrm{MgCl}_{2}, 50 \mathrm{mM}-\mathrm{Tris} / \mathrm{HCl}$ buffer $(\mathrm{pH} 7 \cdot 0)$ and cell extract $\left(1.0 \mathrm{mg}\right.$ protein $\left.\mathrm{ml}^{-1}\right)$ was incubated at $37^{\circ} \mathrm{C}$. As phosphoryl donors, $2.0 \%(\mathrm{w} / \mathrm{v})$ sodium metaphosphate, 
Table 1. Phosphorylation of various sugars by Brevibacterium species

Activities were determined using cell extracts as described in Methods. ND, Not determined.

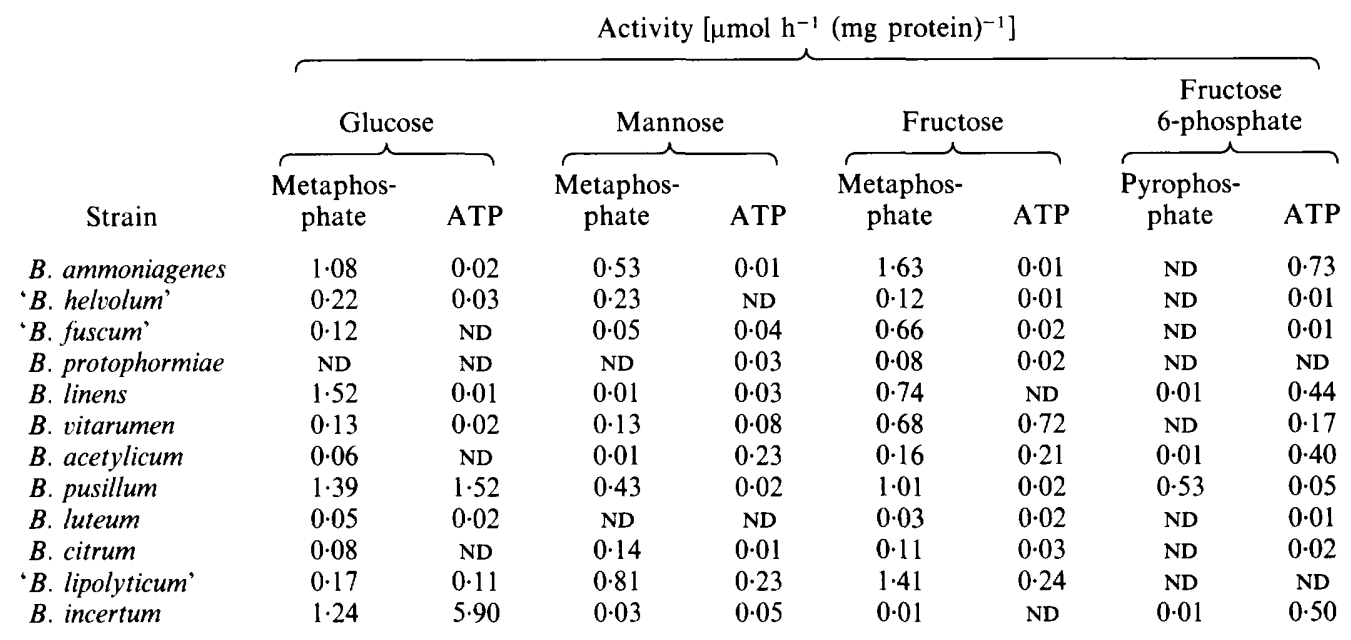

$2.0 \%(\mathrm{w} / \mathrm{v})$ sodium polyphosphate, $10 \mathrm{~mm}$-sodium pyrophosphate and $10 \mathrm{~mm}$-ATP were used. As phosphoryl acceptors, $100 \mathrm{~mm}$-glucose, $100 \mathrm{~mm}$-mannose, $100 \mathrm{~mm}$-fructose and $10 \mathrm{~mm}$-fructose 6-phosphate were used. Metaphosphate (a mixture of ring phosphate polymers) and polyphosphate (a mixture of linear phosphate polymers) were from Nakarai, Kyoto, Japan. The reactions in the absence of phosphoryl acceptors were taken as controls. After incubation for $1 \mathrm{~h}$, reactions were terminated by immersing the test tube in boiling water for $5 \mathrm{~min}$. Sugar phosphate esters formed were determined enzymically. Glucose 6-phosphate, fructose 6-phosphate and fructose 1,6-bisphosphate were determined according to the method of Latzco \& Gibbs (1972). Mannose 6phosphate was determined by the method of Sapico \& Anderson (1967). Activity was expressed as $\mu$ mol sugar phosphate ester formed $\mathrm{h}^{-1}$ (mg protein) $)^{-1}$. Protein was determined by the Lowry method.

\section{RESULTS AND DISCUSSION}

Phosphorylation of various sugars and fructose 6-phosphate by cell extracts prepared from Brevibacterium species is summarized in Table 1. The activities of all the enzymes tested were proportional to reaction time (up to $90 \mathrm{~min}$ ) and protein concentration (up to $2.0 \mathrm{mg} \mathrm{ml}^{-1}$ ) when assayed using cell extracts of $B$. pusillum (Fig. 1). The linearity of reaction rate against reaction time and protein concentration was also confirmed with ATP as phosphoryl donor (data not shown). Almost all the species tested phosphorylated sugars (glucose, mannose, fructose) using metaphosphate as sole phosphoryl donor. ATP was also utilized as a phosphoryl donor, but the ATP-dependent activities were somewhat lower than those observed with metaphosphate. ATP added to the reaction mixture in the absence of phosphoryl acceptors was degraded by cell extracts of $B$. pusillum at a rate of $3.2 \mu \mathrm{mol} \mathrm{h}^{-1}(\mathrm{mg} \text { protein })^{-1}$. Therefore, the low ATPdependent activities seemed to be due to the hydrolysis of ATP during the reaction. In good agreement with the observations of Murata et al. $(1978 ; 1980 \mathrm{~b})$, pyrophosphate and polyphosphates were completely inert as phosphoryl donors for the phosphorylation of sugars, indicating that metaphosphate is more biologically active than polyphosphate. Metaphosphate was without effect in the phosphorylation of fructose 6-phosphate. Of the strains tested, only $B$. pusillum showed a considerably higher activity toward fructose 6-phosphate phosphorylation when pyrophosphate was used as a phosphoryl donor.

We considered that in B. pusillum phosphate polymers were able to replace ATP in the energyrequiring reactions of glycolysis. To analyse the phosphate-polymer-dependent activities, cell extracts of B. pusillum were fractionated on a DEAE-cellulose column (Fig. 2). Metaphosphatedependent sugar phosphorylating activities were separated into two peaks (I and II). The distribution pattern of pyrophosphate-dependent fructose 6-phosphate-phosphorylating activ- 


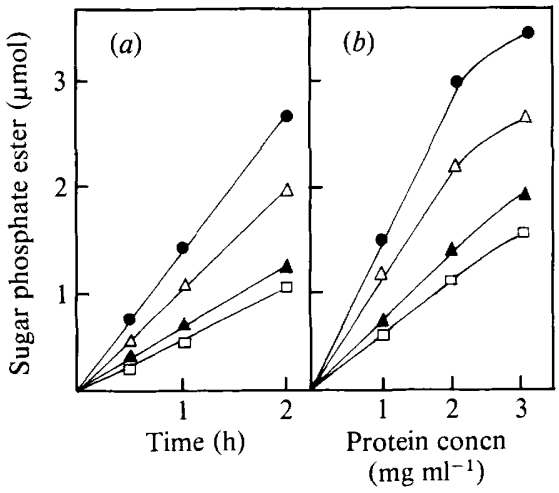

Fig. 1. Dependence of reaction rates on reaction time and protein concentration. The phosphorylation of sugars (glucose, mannose, fructose) and fructose 6-phosphate by cell extracts of $B$. pusillum using metaphosphate and pyrophosphate, respectively, was determined. The amounts of sugar phosphate esters formed were plotted as a function of (a) reaction time (protein concentration $1 \cdot 1 \mathrm{mg} \mathrm{ml}^{-1}$ ), and (b) protein concentration (reaction time $1 \mathrm{~h}$ ). - Metaphosphate-dependent glucose phosphorylating activity; $\boldsymbol{\Delta}$, metaphosphate-dependent mannose phosphorylating activity; $\triangle$, metaphosphatedependent fructose phosphorylating activity; $\square$, pyrophosphate-dependent fructose 6-phosphate phosphorylating activity.

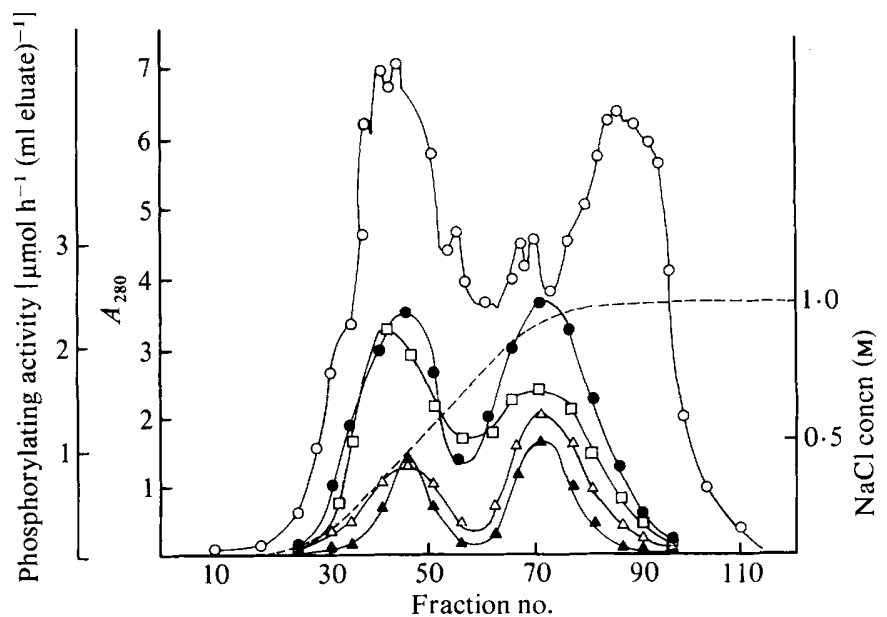

Fig. 2. Separation of phosphate polymer-dependent phosphorylating activities by DEAE-cellulose column chromatography. Cell extracts prepared from $B$. pusillum were fractionated on a DEAEcellulose column and activity in each fraction was determined as described in Methods.---, $\mathrm{NaCl}$ concentration; $\mathrm{O}, A_{280} ; O$, metaphosphate-dependent glucose phosphorylating activity; $\triangle$, metaphosphate-dependent fructose phosphorylating activity; $\Delta$, metaphosphate-dependent mannose phosphorylating activity; $\square$, pyrophosphate-dependent fructose 6-phosphate phosphorylating activity.

ity was very similar to those of metaphosphate-dependent activities, suggesting that $B$. pusillum cells contain at least two distinct enzymes capable of phosphorylating sugars and fructose 6phosphate, respectively.

The substrate specificity of the enzyme in peak I was studied and compared with that of the enzyme in peak II (Table 2). Despite the different phosphoryl donors, the activities of the enzyme in peak I for mannose, fructose and fructose 6-phosphate were approximately one-half the activity for glucose. On the other hand, the activities of the enzyme in peak II for mannose and fructose were almost the same as that for glucose, and activity for fructose 6-phosphate was 


\section{Table 2. Substrate specificity of the enzymes in peaks $I$ and $I I$}

Substrate specificity of the enzyme in peaks I and II was determined as described in Methods. The eluates from a DEAE-cellulose column (Fig. 2) (fraction no. 45 for peak I and fraction no. 70 for peak II) were used as enzyme sources after storage at $-20^{\circ} \mathrm{C}$ overnight.

\begin{tabular}{|c|c|c|c|c|}
\hline \multirow[b]{2}{*}{ Enzyme } & \multirow{2}{*}{$\begin{array}{l}\text { Phosphoryl } \\
\text { acceptor }\end{array}$} & \multicolumn{3}{|c|}{ Activity $\left[\mu \mathrm{mol} \mathrm{h} \mathrm{h}^{-1}(\mathrm{mg} \text { protein })^{-1}\right]$} \\
\hline & & Metaphosphate & Pyrophosphate & ATP \\
\hline \multirow[t]{4}{*}{ Peak I } & Glucose & 0.45 & 0 & 0.42 \\
\hline & Mannose & $0 \cdot 27$ & 0 & $0 \cdot 18$ \\
\hline & Fructose & $0 \cdot 19$ & 0 & $0 \cdot 15$ \\
\hline & Fructose 6-phosphate & 0 & $0 \cdot 20$ & $0 \cdot 16$ \\
\hline \multirow[t]{4}{*}{ Peak II } & Glucose & 0.65 & 0 & 0.37 \\
\hline & Mannose & 0.67 & 0 & 0.35 \\
\hline & Fructose & $0 \cdot 61$ & 0 & 0.34 \\
\hline & Fructose 6-phosphate & 0 & $1 \cdot 58$ & 0.42 \\
\hline
\end{tabular}

very much higher than in peak I. The ATP-degrading activity in peak I (fraction no. 45) was almost the same [approximately $0.50 \mu \mathrm{mol} \mathrm{h}^{-1}$ (mg protein) ${ }^{-1}$ ] as that in peak II (fraction no. 70). Therefore, the results (Table 2) clearly indicate that the enzymes in Peaks I and II are different.

The results presented in Fig. 2 and Table 2 pose three problems. (1) The enzymes in peaks I and II catalyse the same phosphorylation reactions. What are the molecular and functional differences between the enzymes? (2) The enzymes in peaks I and II utilize both phosphate polymers and ATP as phosphoryl donors. Is it possible to separate phosphate-polymerdependent activity from the ATP-dependent one? (3) The metaphosphate used was a mixture of ring phosphate polymers with various $M_{\mathrm{r}}$ values. Are the intrinsic substrates for sugar phosphorylations the same as this or different? The study of these problems is in progress.

Thus, in B. pusillum phosphate polymers appear to function as potent phosphoryl donors for the phosphorylation of glycolytic substrates. Organisms of the genus Brevibacterium are utilized for the industrial production of amino acids, nucleic acid bases, nucleosides and nucleotides. The elucidation of the function of phosphate polymers in these strains might, therefore, provide some novel information relating their high capacity for producing useful compounds to phosphate-polymer-dependent energy transduction. The study of the function of phosphate polymers may also provide some information as to the evolution of energy carriers preceding ATP.

We thank Dr M. Sakaguchi for his continuous discussion on this work.

\section{REFERENCES}

Carnal, N. W. \& Black, C. C. (1979). Pyrophosphate-dependent 6-phosphofructokinase activity in germinating pea seeds. Biochemical and Biophysical Research Communications 86, 20-26.

Cseke, C., Weeden, N. F., Buchanan, B. B. \& UYEDA, K. (1982). A special fructose bisphosphate function as a cytoplasmic regulatory metabolite in green leaves. Proceedings of the National Academy of Sciences of the United States of America 79, 43224326.

HAROLD, F. M. (1966). Inorganic polyphosphate in biology: structure, metabolism, and function. Bacteriological Reviews 30, 772-794.

Kruger, N. J., Kombrink, E. \& BeEvers, H. (1983). Pyrophosphate:fructose 6-phosphate phosphotransferase in germinating castor bean seedlings. FEBS Letters 153, 409-412.
LatzCo, E. \& GibBS, M. (1972). Measurement of the intermediates of the biosynthetic carbon reduction cycle, using enzymatic methods. Methods in Enzymology 24, 261-268.

Murata, K., Kato, J. \& Chibata, I. (1978). Properties of polyphosphate glucokinase in Achromobacter butyri. Agricultural and Biological Chemistry 42, 2221-2226.

Murata, K., Uchida, T., Tani, K., Kato, J. \& Chibata, I. (1980a). Metaphosphate-dependent nicotinamide adenine dinucleotide kinase from Brevibacterium ammoniagenes. Agricultural and Biological Chemistry 44, 1165-1172.

Murata, K., Uchida, T., Tani, K. Kato, J. \& Chibata, I. $(1980 b)$. Metaphosphate: a new phosphoryl donor for NAD phosphorylation. Agricultural and Biological Chemistry 44, 61-68. 
O'Brien, W. E., Bowien, S. \& WoOd, H. G. (1975). Isolation and characterization of a pyrophosphatedependent phosphofructokinase from Propionibacterium shermanii. Journal of Biological Chemistry 250. 8690-8695.

Reeves, R. E., South, D. J., Blytt, H. J. \& Warren, L. G. (1974). Pyrophosphate:D-fructose-6-phosphate-1-phosphotransferase. Journal of Biological Chemistry 249, 7737-7741.

Sabularse, D. C. \& Anderson, R. L. (1981). DFructose 2,6-bisphosphate: a naturally occurring activator for inorganic pyrophosphate: $D$-fructose-6phosphate-1-phosphotransferase. Biochemical and Biophysical Research Communications 103, 848-855.

SAPICO, V. \& ANDERSON, R. L. (1967). An adenosine 5'triphosphate: hexose-6-phosphotransferase specific for D-mannose and D-fructose from Leuconostoc mesenteroides. Journal of Biological Chemistry 242, 5086-5091. van Schaftingen, E., Lederer, B., Bartron, R. \& Hers, H. G. (1982). A kinetic study of pyrophosphate:fructose-6-phosphate phosphotransferase from potato tubers. European Journal of Biochemistry 129, 191-195.

Stitt, M., Mieskes, G., Soling, H.-D. \& Heldt, H. W. (1982). On a possible role of fructose 2,6bisphosphate in regulating photosynthetic metabolism in leaves. FEBS Letters 145, 217-222.

Tyron, V. V. \& Pollack, D. (1984). Purine metabolism in Acholeplasma laidlawii $\mathrm{B}$ : novel $\mathrm{PP}_{\mathrm{i}}$ dependent nucleoside kinase activity. Journal of Bacteriology 159, 265-270.

Wu, M.-M., SMYth, D. A. \& Black, C. C. (1983). Fructose 2,6-bisphosphate and the regulation of pyrophosphate-dependent phosphofructokinase activity in germinating pea seeds. Plant Physiology 73, 188-191. 